\title{
Value Engineering for the Optimisation of Micro-Hydro Power Plant in Kampung Assum, Sarawak
}

\author{
Sim NeeTing ${ }^{\mathrm{a}, *}$, Jefferson Kiong Leong Yong ${ }^{\mathrm{a}}$ and Nicholas Hoo Tien Kuan ${ }^{\mathrm{b}}$ \\ ${ }^{a}$ Department of Civil Engineering, Faculty of Engineering, Universiti Malaysia Sarawak, \\ 94300 Kota Samarahan, Sarawak, Malaysia \\ ${ }^{b}$ Department of Mechanical and Manufacturing Engineering, Faculty of Engineering, \\ Universiti Malaysia Sarawak, 94300 Kota Samarahan, Sarawak, Malaysia
}

\begin{abstract}
Most rural locations in East Malaysia are not electricity grid connected. These places rely heavily on high-cost diesel fuels for generating electric power, which can be environmentally unfriendly. Most of all, this situation hampered the potential growth in terms of economic productivity and developments in these rural locations. However, with the vast network of streams and rivers available in Sarawak, there are high prospective of constructing micro-hydro power plant as electricity generating alternative. Efforts and studies on micro hydro power plants have been put in place. However, there exists a gap in the field of study of optimized design and construction of micro-hydropower system. This project proposed a Value Engineering (VE) study in the civil and structure sections of microhydro plant in Kampung Assum, Sarawak in order to achieve high functional value for the facility. VE Job Plan was utilized as the backbone of this research study framework. VE calculation modelling is produced and conventional micro-hydro power plant is designed using the modelling as control baseline design. Ideas to further optimise and improve the value of the micro-hydro system are generated and evaluated, which are then compared with the control baseline design. Determination of value for micro-hydropower system is dependent on the cost incurred and the efficiency of the civil and structural components as a whole. The chosen idea is then used to the next development phase which notable changes in parameters of micro-hydro civil structures are further determined to improve the value. In this study, evaluating the micro-hydro civil components as a whole with adjustments made to modify the overall output data are discovered to be the prominent idea. From this study, the optimisation proposed could improved the functional value of the micro-hydro power plant in Kampung Assum by $17 \%$.
\end{abstract}

Keywords: Value Engineering, Optimisation, Micro-Hydro, Power, Plant, Kampung Assum, Sarawak

\section{Introduction}

Value Engineering (VE), is defined as a multi-disciplinary, team oriented, structured, analytical process and systematic analysis of function. It seeks the best value via the design and construction process to meet the intended purposes or perceived needs (Jaapar, 2004). This method often leads to reduced costs and improved quality of the end product. The main objective of conducting VE is to generate cost improvement without sacrificing the intended performance levels. VE ensures quality,

* Corresponding author. Tel.: +60-082-583293; fax: +60-082-583410

E-mail address: snting@unimas.my

Manuscript History:

Received 1 August, 2019, Revised 25 September, 2019, Accepted 28 September, 2019, Published 30 September, 2019

e-ISSN: $2289-7771$

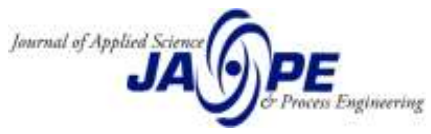


reliability, performance that correlates with the client's expectations. In addition to that, identifications of faults and problems are part of VE objectives. VE studies are based on the faults and problems of existing projects and produce alternatives that are creative productive and economically to solve the problems and faults. VE can be applied in any stages during the project life cycle. However, optimum stages to apply VE are during the initial stages of a project to achieve maximum benefits for VE applications (Sadawi, 2008).

There are several procedures and techniques that could be adopted in construction projects. The most prominent procedure of conducting VE study is the VE Job Plan. It is an application of recognized tool and techniques by multidisciplinary team to identify and categorize the functions of a project to create, develop and select alternative approach to efficiently deliver the function and improve performance while reducing costs. According to Davis, 2004; Liu \& Leung, 2002, Alwerfalli \& Schaaf, 2010, there are seven (7) phases in total in the VE Job Plan namely: information phase, function analysis phase, creative phase, evaluation phase, development phase, presentation phase and implementation phase. The ultimate goal of VE is to determine the value of the projects conducted where

$$
\text { Value }=\frac{\text { Function }+ \text { Quality }}{\text { Cost }}
$$

(Source: Dell’'Isola, 1988)

As Malaysia progresses towards a developed nation status which it hopes to be achieved at the year 2020, the contributions of the construction industry in Malaysia to the development of the nation are of utmost importance. This includes development of the rural areas and construction of renewable and sustainable energy facilities. In Sarawak alone, a total of 155 potential sites are identified for hydropower facilities, where many are suitable for micro-hydro power plants. Furthermore, series of micro-hydro power plants are expected to be introduced to 47 villages of Sarawak, an initiative by the people's Institute of Business and Economy and United Nations Economic and Social Commission for Asia and the Pacific (The Malaysian Reserve, 2014).

\section{Problem statement}

According to Locke (2001), application of VE in the construction industry can generate return of investment of 30:1. With an initial investment of 22 million, the estimated total financial savings can be generated up to RM 670 million. There is, however, lack of VE studies on the optimization of micro-hydro power plant which has gained popularity as an option for rural energy supply. Due to the high potential of micro-hydro development all across Sarawak, application of VE in micro-hydro projects are becoming necessary to be incorporated into the feasibility and design for micro-hydro power plant projects to ensure proper evaluation of function and cost. It is essential to provide an optimized and highly functional micro-hydro to rural communities that are separated from local grid lines especially the rural areas of Sarawak as it is their only power source.

VE has proven track records around the world for the ability to save costs while improving the functionality and performance of the intended activity. It is the main aim of this study to carry out an in-depth study of the value of micro-hydro power plant designed for rural locations in Sarawak. Using Kampung Assum, Sarawak as a case study, VE study was proposed. Several aspects of the microhydro components are taken into consideration for VE study purposes. Among the general design consideration that can be determined in the micro-hydro design are (Steven, 2003):

i) Overall Stability-The whole structure should not sink, float, overturn, slide or imposed excess loads on the ground.

ii) Element Design-The reinforced concrete walls/bases should have sufficient reinforcement and adequate thickness. 
iii) Materials-Considerations on whether materials are adequate or appropriate depending on the surroundings and environmental conditions.

As such, VE studies and analysis were carried on civil and structural components of microhydro power plant proposed. Civil and structural works are significant and critical components that have high potential for design improvements and cost savings based on a risk and value approach (Ong, 2003). This aspect is crucial to develop a more efficient and appropriate technology for the rural community of Sarawak. Among the civil and structural components under study are: Intake structure/ Orifice, Headrace Canal, Penstock, Spillway, Forebay Tank, Settling Basin.

\section{Methodology}

The following provides the overall methodology used in this study.

a) Pre-workshop Study

Pre-workshop study is conducted in the initial stage of this VE study. Among the studies done during this stage includes preliminary studies and feasibility studies. These studies are done by obtaining relevant information on the project through interviews, gathering past data and geological data as shown in Figure 1 and Figure 2.

\begin{tabular}{|l|c|}
\hline \multicolumn{1}{|c|}{ Features } & Preliminary Survey Data \\
\hline Gross Head & $0.3 \mathrm{~m}$ \\
\hline Measured Flow & $0.25 \mathrm{~m}^{3} / \mathrm{s}$ \\
\hline Least Flow & $0.5 \mathrm{~m}$ above water level \\
\hline Design Flood Level & $0.8 \mathrm{~m}$ \\
\hline Water Level & $0.10 \mathrm{~m}^{3} / \mathrm{s}$ \\
\hline Design Discharge & 2.65 \\
\hline Sedimentation Weight of Sediment Particles & 0.0002 \\
\hline Particle Diameter & 28 \\
\hline Temperature of Water & Kampung Assum, Sungai Sebarong \\
\hline River Source & 15000 Watts / 15 kW \\
\hline Power & 100 Households \\
\hline No of Household Demand & \\
\hline
\end{tabular}

Figure 1. Preliminary data for Kampung Assum (preliminary studies). 


\begin{tabular}{|l|l|}
\hline \multicolumn{1}{|c|}{ Parameters } & \multicolumn{1}{c|}{ Description } \\
\hline Surrounding Environment & $\begin{array}{l}\text { Kampung Assum are considered as rural area and the } \\
\text { access route, clean water and electricity supply are not } \\
\text { available in the village. } \\
\text { Located next to Sungai Sebarong where water flow is } \\
\text { constant. }\end{array}$ \\
\hline $\begin{array}{l}\text { Current Available Electricity } \\
\text { Supply }\end{array}$ & $\begin{array}{l}\text { Generator set are available at few household but are of } \\
\text { high maintenance. } \\
\text { Government supply generator set are being swept } \\
\text { away in big flood in year 2003 are since then been } \\
\text { abandoned. }\end{array}$ \\
\hline Topography & $\begin{array}{l}\text { No reliable source of electricity supply at the moment. } \\
\text { Suitable for installation of hydro-powered generator } \\
\text { as the village is located only } 3 \text { kilometers from the } \\
\text { river. } \\
\text { solar and wind powered generator due to thick forest } \\
\text { and lack of constant wind. }\end{array}$ \\
\hline
\end{tabular}

Figure 2. Feasibility studies for Kampung Assum micro-hydro power plant.

b) Workshop Study

During the workshop study, information phase, function analysis phase, creative phase and evaluation phase were executed. During this stage, technical data was interpreted and creative ideas were produced to improve and ameliorate the value of micro-hydro power plant under study. Interviewees who are experienced with micro-hydro projects and hydro projects were invited to the workshop. Six (6) individuals comprising of engineers, contractors and researchers were invited to give their opinions of the study.

\section{Results and analysis}

The following presents the results of the analysis of Kampung Assum micro-hydro power plant civil and structural component.

Information Phase - the basic component of micro-hydro power plant for civil and structural component are described in the following Figure 3. 


\begin{tabular}{|l|l|}
\hline \multicolumn{1}{|c|}{ Civil Components } & \multicolumn{1}{c|}{ Functions } \\
\hline Weir and intake & - Extract water from river in a controllable manner \\
& - Regulate water flow during high and low river flow \\
& - Raise water level to ensure constant supply to the water intake \\
\hline Headrace Canal & - Conducts water from the intake to the settling basin \\
\hline Settling Basin & - Ensure hard abrasive sediment does not passes through \\
\hline Spillways & - Flush sediments that settles periodically \\
\hline Forebay Tank & - To permit controlled overflow of the micro-hydro system \\
& - Act as a flow regulator for channel \\
\hline Penstock & - Trash rack are installed to filter particles entering penstock \\
\hline
\end{tabular}

Figure 3: Basic function of civil component in micro-hydro power plant.

Function Analysis - functions of micro-hydro power plant are brainstormed and produced. The primary outcomes are analysed and arranged in accordance to its relativity and significance. Definition of function for micro-hydro power plant in Kampung Assum is produced and shown in Figure 4.

\begin{tabular}{|l|l|l|l|l|}
\hline Theme & Function & Primary & Secondary & Others \\
\hline $\begin{array}{l}\text { Develop a VE } \\
\text { methodology for } \\
\text { Micro Hydro Project } \\
\text { in Kampung Assum }\end{array}$ & $\begin{array}{l}\text { Supply reliable and efficient } \\
\text { generation of electricity } \\
\text { through micro hydro power } \\
\text { plant }\end{array}$ & & & \\
\cline { 2 - 5 } & $\begin{array}{l}\text { Ensure optimisation of civil } \\
\text { components in micro hydro } \\
\text { power plant }\end{array}$ & $/$ & & \\
\hline & $\begin{array}{l}\text { To maximise the value of micro } \\
\text { hydro power plant through } \\
\text { costing evaluation }\end{array}$ & $/$ & & \\
\hline & $\begin{array}{l}\text { Improve living standard of } \\
\text { villagers in Kampung Assum }\end{array}$ & & & \\
\hline & $\begin{array}{l}\text { Ensure natural environment are } \\
\text { preserved and not affected by } \\
\text { development }\end{array}$ & & & \\
\hline
\end{tabular}

Figure 4: Definition of function for micro-hydro power plant in Kampung Assum.

From the primary functions defined, these functions were then further level out in accordance to its relativity and significance as shown in Table 1 . This step would be repeated for every primary function. 
Table 1: Significance and relativity of function arrangement for first primary function

\begin{tabular}{|c|c|c|}
\hline First Level & Second Level & Third Level \\
\hline \multirow{6}{*}{$\begin{array}{l}\text { Maximize value of } \\
\text { micro hydro power } \\
\text { plant through costing } \\
\text { evaluation }\end{array}$} & \multirow[t]{3}{*}{$\begin{array}{l}\text { Selection of civil structures } \\
\text { components that are cost } \\
\text { effective }\end{array}$} & $\begin{array}{l}\text { Compare the cost of different materials used } \\
\text { in civil structures against the output } \\
\text { respectively }\end{array}$ \\
\hline & & $\begin{array}{l}\text { Adjust the cross-sectional area or the size of } \\
\text { civil component to compare the output } \\
\text { against the cost incurred }\end{array}$ \\
\hline & & $\begin{array}{l}\text { Selection of materials that are readily } \\
\text { available locally to save on transportation } \\
\text { costs }\end{array}$ \\
\hline & \multirow{3}{*}{$\begin{array}{l}\text { Determining of the return } \\
\text { on investment for } \\
\text { construction of micro- } \\
\text { hydro in Kampung Assum }\end{array}$} & $\begin{array}{l}\text { Evaluate the cost saved for the long run as } \\
\text { compared to other alternatives }\end{array}$ \\
\hline & & $\begin{array}{l}\text { Determine the initial cost and compare with } \\
\text { other alternatives }\end{array}$ \\
\hline & & $\begin{array}{l}\text { Ascertain the cost against the function of the } \\
\text { micro-hydro power plant project in } \\
\text { Kampung Assum }\end{array}$ \\
\hline
\end{tabular}

After defining and arranging the functions for the micro-hydro project in Kampung Assum, the importance level are then ranked and evaluated as shown it the following sections. Dominations between the functions are then determined. The domination of functions uses Forced Decisions approach (Ando, 2003) as shown in Figure 5. From the analysis done, selection of structure components that are cost effective are the most important function which scored at $66.7 \%$. Determining the return of investment for the construction of micro-hydro came in after the latter at $33.3 \%$. This shows a strong focus in the analysis of structural components for the plant. 
Primary Function: Supply reliable generation of electricity through micro-hydro power plant

\begin{tabular}{l} 
No. Function \\
\cline { 2 - 5 }
\end{tabular}

Figure 5: Results of importance judgment classified by function for first primary function.

Creative Phase - Idea deposition are initiated during this phase. The ideas and suggestions provided and proposed are illustrated. In order to facilitate the process of creative phase, a VE calculation model for micro-hydro power plant calculation is created for the study. Design technical calculations focused on six different civil components in micro-hydro power plant which is side intake, headrace canal, spillway, settling basin, penstock and forebay tank.

Figure 6 to 11 below show each of the calculations for six (6) civil and structural components produced for the VE calculation sheets.

\begin{tabular}{|c|c|c|}
\hline Features & Parameters & Units \\
\hline Design Flow & Qrequired & $\mathrm{m} 3 / \mathrm{s}$ \\
\hline Normal Water Level in River & hr & $\mathrm{m}$ \\
\hline Design Flood Level & hf & $\mathrm{m}$ \\
\hline $\begin{array}{l}\text { Velocity of Water Passing Through } \\
\text { Orifice }\end{array}$ & $\mathrm{v}$ & $\mathrm{m} / \mathrm{s}$ \\
\hline Area of Orifice & $A=Q \times V$ & $\mathrm{~m} 2$ \\
\hline Water Level at Headrace Canal & hh & $\mathrm{m}$ \\
\hline Delivery of Side Intake & $\begin{array}{l}\text { Qdesign=A.V=A.CV2.g(hr- } \\
\text { hh) }\end{array}$ & $\begin{array}{c}\mathrm{m} 3 / \mathrm{s} \\
1 / \mathrm{s}\end{array}$ \\
\hline Critical Delivery of Side Intake & $\begin{array}{l}\text { Qfiood }=A, V=A \cdot C V 2 \cdot g(h+- \\
h h)\end{array}$ & $\begin{array}{c}\mathrm{m} 3 / \mathrm{s} \\
1 / \mathrm{s}\end{array}$ \\
\hline
\end{tabular}

Figure 6: Design of orifice/side intake. 


\begin{tabular}{|c|c|c|}
\hline \multirow{2}{*}{$\begin{array}{l}\text { Features } \\
\text { Design Flow }\end{array}$} & Parameters & \multirow{2}{*}{$\begin{array}{l}\text { Units } \\
\mathrm{m3} / \mathrm{s}\end{array}$} \\
\hline & Qrequired & \\
\hline Roughness coefficient & $n$ & \\
\hline Side Slope & $\mathrm{N}=\mathrm{h} / \mathrm{v}$ & \\
\hline Velocity Passing in Headrace Canal & $\mathrm{v}$ & $\mathrm{m} / \mathrm{s}$ \\
\hline Cross Sectional Area for Headrace Canal & $A=Q / V$ & $\mathrm{~m} 2$ \\
\hline Determining Coefficient & $X=2 V\left(1+N^{\wedge} 2\right)-2 N$ & \\
\hline Depth of Canal & $H=V A /(x+N)$ & $\mathrm{m}$ \\
\hline Bed Width of Canal & $B=H \times x$ & m \\
\hline Top Width of Canal & $\mathrm{T}=\mathrm{B}+(2 \mathrm{HN})$ & $m$ \\
\hline Critical Velocity & $V c=V(A g / T)$ & $\mathrm{m} / \mathrm{s}$ \\
\hline $80 \%$ of Critical Velocity & $0.8 \mathrm{Vc}$ & $\mathrm{m} / \mathrm{s}$ \\
\hline Wetted Perimeter of Canal & $\mathrm{P}=\mathrm{B}+2 \mathrm{H} \times \mathrm{V}\left(1+\mathrm{N}^{\wedge} 2\right)$ & $m$ \\
\hline Hydraulic Radius & $R=A / P$ & $\mathrm{~m}$ \\
\hline Bed Slope & $S=\left(n \vee / R^{\wedge} 0.667\right)^{\wedge} 2$ & \\
\hline Bed Slope Ratio (1:Ans) & $\mathrm{s}$ & \\
\hline Head Loss & LXS & m \\
\hline Optimal Height for Canal Bed & $\mathrm{H}$ & \\
\hline \multirow[b]{2}{*}{ Largest Particle Size } & $d=11 R S$ & $\mathrm{~m}$ \\
\hline & & $\mathrm{mm}$ \\
\hline
\end{tabular}

Figure 7: Design of headrace canal.

Design of Settling Basin

\begin{tabular}{|c|c|c|}
\hline Features & Parameters & Units \\
\hline \multicolumn{3}{|l|}{ Ratio of Width of Settling Basin and Headrace Canal } \\
\hline Width of Settling Basin & W & $\mathrm{m}$ \\
\hline Design Flow & Q & $m^{\wedge} 3 / s$ \\
\hline Sedimentation Weight of Sediment Particles & $\mathrm{Y}_{\mathrm{s}}$ & $\mathrm{g} / \mathrm{cm}^{\wedge} 3$ \\
\hline Specific Weight of Water & Yw & $\mathrm{g} / \mathrm{cm}^{n} 3$ \\
\hline Temperature of Water & $t$ & ${ }^{\circ} \mathrm{C}$ \\
\hline Kinetic Viscosity & $\mathrm{v}$ & \\
\hline Particle Diameter & d & m \\
\hline Fall Velocity & Vvertical & $\mathrm{m} / \mathrm{s}$ \\
\hline Settling Length & Letting $=(2 \times 0 / W \times V$ vertical $)$ & $\mathrm{m}$ \\
\hline Expected Silt Load & Slood $=Q \times T \times C$ & $\mathrm{~kg}$ \\
\hline Volume of Silt Load & VOsilt=Sloas/(Sdenver/Ptactor $)$ & $\mathrm{m3}$ \\
\hline Depth Required for Average Silt Collection & Doclection=VOsil//(LetsingXW) & m \\
\hline
\end{tabular}

Figure 8: Design of settling basin. 


\begin{tabular}{|c|c|c|}
\hline Features & Parameters & Units \\
\hline \multicolumn{3}{|l|}{ Penstock Loss Calculation } \\
\hline Diameter of Pipe & dope & $\mathrm{m}$ \\
\hline Penstock Length & $\mathrm{L}$ & m \\
\hline Gross Head & $\mathrm{He}_{\mathrm{E}}$ & m \\
\hline Design Discharge & Q & $1 / 5$ \\
\hline Average Velocity in Pipe & $V=1273 \times\left(Q / d^{\wedge} 2\right)$ & $\mathrm{m} / \mathrm{s}$ \\
\hline Friction Head Loss & $H f=12.8 \times\left(V^{\wedge} 2 \times L / d\right) \times(1 /(\log (1 / 37 d+1 /(93.8 V \times d \wedge 0.9) 2)$ & m \\
\hline Net Head & $\mathrm{H} n=\mathrm{H}_{8}-\mathrm{HH}$ & $\mathrm{m}$ \\
\hline Penstock Efficiency & $\Pi_{\text {een }}=\left(\mathrm{H}_{2} / \mathrm{H}\right.$ gix $100 \%$ & 9 \\
\hline \multicolumn{3}{|l|}{ Penstock Thickness Calculation } \\
\hline Penstock Thickness & $t$ & $\mathrm{~mm}$ \\
\hline \% of flow stopped & 2 & $\%$ \\
\hline Valve Closure Time & Tolose & seconds \\
\hline Corrosion Allowance & teer & $\mathrm{mm}$ \\
\hline Overall Safety Factor & SF & \\
\hline Wave Velocity & $V_{\text {nave }}=\mathrm{V}(2.1 \mathrm{e} 8 \mathrm{xt}) /(100 \mathrm{t}+\mathrm{d})$ & $\mathrm{m} / \mathrm{s}$ \\
\hline Penstock Critical Time & Terit $=24 / V_{\text {wave }}$ & seconds \\
\hline Surge Head (Kc) & $K_{c}=\left((L C 2 \times V) /\left(980 H_{p} \times T_{d o s e}\right)\right)^{n} 2$ & \\
\hline Surge Head (TdoukTent) & Hsurge $=H g\left((K c / 2)+V K_{c}+K_{c} c^{\wedge} 2 / 4\right)$ & m \\
\hline Total Head at Surge & Heos=Houret+He & m \\
\hline Required Penstock Thickness & treq $=($ HtosodxSFtor $/ 83700)+$ tcor & $\mathrm{mm}$ \\
\hline
\end{tabular}

Figure 9 Design of penstock pipe.

Design of Forebay Tank

\begin{tabular}{|l|l|l|c|}
\hline Features & \multicolumn{1}{|c|}{ Parameters } & Units \\
\hline Submergence Head & hs $21.5 V^{\wedge} 2 / 2 \mathrm{~g}$ & & $\mathrm{~m}$ \\
\hline Young Modulus of Penstock Material & $\mathrm{E}$ & & \\
\hline Safety Factor & $\mathrm{F}$ & & \\
\hline Diameter of Air Vent & $\mathrm{d}^{\wedge} 2=\mathrm{QV}\left((\mathrm{F} / \mathrm{E})\left(\mathrm{D} /\right.\right.$ teffective $\left.^{\wedge}{ }^{3}\right)$ & & $\mathrm{mm}$ \\
\hline
\end{tabular}

Lezend input Data

Output Data

Figure 10: Design of forebay tank.

Design of Spillway

\begin{tabular}{|c|c|c|}
\hline Features & Parameters & Units \\
\hline Length of Spillway & 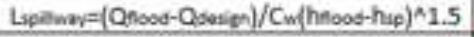 & m \\
\hline Length of Spillway (Critical) & Lspillway=(Qflood)/CW(hflood-hsp)^1.5 & m \\
\hline Flood Flow via intake & Qflood: & $\mathrm{m} 3 / \mathrm{s}$ \\
\hline Design Flow in Headrace Canal & Qtesim & $\mathrm{m} 3 / \mathrm{s}$ \\
\hline Height of Flood Level in Canal & hrloos & $\mathrm{m}$ \\
\hline $\begin{array}{l}\text { Height of Spillway Crest from Canal } \\
\text { Bed }\end{array}$ & hig & m \\
\hline Overtop Height & hovertos: & $\mathrm{m}$ \\
\hline Coefficient of Weir & $C_{w}$ & \\
\hline
\end{tabular}

Lenend:

Output Dota

Figure 11: Design of spillway. 
Figure 12 below shows the overall baseline efficiency, cost and value for every civil and structural component for a conventional micro-hydro power plant design that was used for Kampung Assum. The value of each component is rated as mentioned in previous Equation (1).

Value of Overall Micro-Hydro
\begin{tabular}{|l|r|r|r|}
\hline Civil Component & Efficiency & \multicolumn{1}{l|}{ Cost } & \multicolumn{1}{l|}{ Value } \\
\hline Orifice / Side Intake & 100 & 5821.1848 & 1.717863346 \\
\hline Headrace Canal & 99.07378186 & 6588.435064 & 1.503752878 \\
\hline Settling Basin & 100 & 3955.976891 & 2.527820631 \\
\hline Penstock & 100 & 3381.660394 & 2.95712722 \\
\hline Forebay Tank & 94.09090909 & 11424.49818 & 0.823588989 \\
\hline & & Total Value & 9.530153064 \\
\cline { 2 - 4 } & & Average Value & 1.906030613 \\
\cline { 3 - 5 }
\end{tabular}

Figure 12: Value Determination of Micro-Hydro

Evaluation Phase - During the evaluation process, the VE team compared every idea with the baseline concept to determine whether it was better than or equal to, or worse than the original design concept. In addition to that, advantages and disadvantages of the idea proposed were determined for the idea proposed during the creative phase. There were altogether six (6) ideas proposed as shown in Table 2.

Table 1: Deposition of ideas for Kampung Assum micro-hydro power plant design civil and structural components

\begin{tabular}{|l|l|c|l|}
\hline \multicolumn{1}{|c|}{ Description/Ideas } & \multicolumn{1}{|c|}{ Methodology } & \multicolumn{1}{c|}{ Materials } & \multicolumn{1}{c|}{ Design } \\
\cline { 2 - 4 } & \multicolumn{1}{|c|}{ No changes } & No changes & \multicolumn{1}{c|}{ No changes } \\
\hline $\begin{array}{l}\text { 1. No action } \\
\text { componenaluate each civil } \\
\text { its optimum performance } \\
\text { individually }\end{array}$ & $\begin{array}{l}\text { Each component is } \\
\text { analyzed separately and } \\
\text { lastly to produce an } \\
\text { optimum overall result }\end{array}$ & $\begin{array}{l}\text { Design of each civil } \\
\text { component are } \\
\text { changed to satisfy } \\
\text { the optimum output } \\
\text { for individual } \\
\text { component }\end{array}$ \\
\hline $\begin{array}{l}\text { 3.Evaluate the micro- } \\
\text { hydro civil components as } \\
\text { a whole where } \\
\text { adjustments made to } \\
\text { modify overall output }\end{array}$ & $\begin{array}{l}\text { Only civil component that } \\
\text { are affected is adjusted of } \\
\text { its parameters to improve } \\
\text { the overall performance }\end{array}$ & $\begin{array}{l}\text { Materials may } \\
\text { be adjusted to } \\
\text { compliment the } \\
\text { parameter of } \\
\text { civil structure } \\
\text { before and after }\end{array}$ & $\begin{array}{l}\text { Design is } \\
\text { considered and } \\
\text { adjusted according } \\
\text { to the overall } \\
\text { output performance }\end{array}$ \\
\hline $\begin{array}{l}\text { 4. Determine the } \\
\text { minimum sections, } \\
\text { thickness and areas to } \\
\text { reduce the parameters } \\
\text { mentioned in order to } \\
\text { reduce costs }\end{array}$ & $\begin{array}{l}\text { Ascertain the margin of } \\
\text { safety and the provided } \\
\text { sections parameter in order } \\
\text { to minimize wastages of } \\
\text { material from over- } \\
\text { designing of civil } \\
\text { components }\end{array}$ & $\begin{array}{l}\text { Design parameters } \\
\text { is minimized and } \\
\text { reduced within } \\
\text { safety limits }\end{array}$ \\
\hline
\end{tabular}




\begin{tabular}{|l|l|c|l|}
\hline $\begin{array}{l}\text { 5. Selection of materials } \\
\text { that are cost effective to } \\
\text { reduce construction costs }\end{array}$ & $\begin{array}{l}\text { Replace materials with } \\
\text { more cost friendly materials } \\
\text { which are available locally } \\
\text { to reduce transportation } \\
\text { costs }\end{array}$ & $\begin{array}{l}\text { Changes of } \\
\text { materials that } \\
\text { are less costly }\end{array}$ & Nil \\
\hline $\begin{array}{l}\text { 6. Integrate the civil } \\
\text { components with the } \\
\text { topography to reduce the } \\
\text { landscaping cost }\end{array}$ & $\begin{array}{l}\text { Understand the topography } \\
\text { of the proposed micro- } \\
\text { hydro location and integrate } \\
\text { the civil component design } \\
\text { within it }\end{array}$ & Nil & $\begin{array}{l}\text { Design parameters } \\
\text { are according to } \\
\text { local topography } \\
\text { and values are } \\
\text { variable with } \\
\text { different site of } \\
\text { micro hydro }\end{array}$ \\
\hline
\end{tabular}

From the value obtained, the VE team then rated each of the ideas based in the value improvement or degradation and the advantages and disadvantages are listed out as shown in the following Figure 13. Below are the summary for efficiency, costing, value and ranking of each ideas produced by the VE team.

\begin{tabular}{|c|c|c|c|c|c|}
\hline Idea No. & Efficiency (\%) & Price (RM) & Value & Significance (\%) & Ranking \\
\hline $\mathbf{1}$ & 96.58 & $31,171.76$ & 1.906 & 16.61 & $3 / 4$ \\
\hline $\mathbf{2}$ & 97.86 & $31,571.44$ & 1.903 & 16.58 & 5 \\
\hline $\mathbf{3}$ & 99.47 & $31,356.30$ & 1.950 & 17.00 & 1 \\
\hline $\mathbf{4}$ & 91.57 & $30,329.78$ & 1.882 & 16.40 & 6 \\
\hline $\mathbf{5}$ & 97.22 & $29,513.55$ & 1.906 & 16.61 & $3 / 4$ \\
\hline $\mathbf{6}$ & 87.50 & $27,180.04$ & 1.928 & 16.80 & 2 \\
\hline Total & & & 11.475 & 100 & \\
\hline
\end{tabular}

Figure 13: Summary for Efficiency, Costing Value and Ranking

According to the summary above, Idea 3 is ranked the highest and hence the idea is adopted and integrated in the upcoming micro-hydro power plant. Idea 3 proposed is to evaluate the micro-hydro civil components as a whole where adjustments made to modify overall output. This implies that the modifications and alteration are made from the output data perspective to optimize the micro hydro components as a whole. Hence, among the changes that are made to the VE modelling are:

- Area of orifice / side intake: $0.09 \mathrm{~m} 2$ (control: $0.13 \mathrm{~m} 2$ )

- Water level at headrace canal: $0.4 \mathrm{~m}$ (control: $0.5 \mathrm{~m})$

- Side slope for headrace canal: 0.8 (control: 0.5 ) 
- Velocity passing in headrace canal: $0.8 \mathrm{~m} / \mathrm{s}$ (control: $0.9 \mathrm{~m} / \mathrm{s}$ )

- Diameter of penstock: $0.3 \mathrm{~m}$ (control: $0.25 \mathrm{~m}$ )

- Penstock Thickness: $2 \mathrm{~mm}$ (control: $2.5 \mathrm{~mm}$ )

- Safety factor of forebay tank: 3 (control: 5)

The changes made for Idea 3 are based on the alteration of parameters for all the civil structures based on the output data given. Hence the summary of the results are produced for Idea 3 as shown in the following Figure 14.

The costing for the overall micro hydro power plant is RM 31, 356.30. There is a slight increase of RM 184.50 as compared to the control design which can be considered as negligible changes.

Efficiency Rating

\begin{tabular}{|c|c|c|c|}
\hline Description & Formulae & Results & Units \\
\hline Headrace Canal Efficiency & (Hg-HeadLoss) $/ \mathrm{Hg} \times 100$ & 99.3025507 & $\%$ \\
\hline Penstock Efficiency & $\eta$ pen $=(\mathrm{Hn} / \mathrm{Hg}) \times 100 \%$ & 99.62839067 & $\%$ \\
\hline
\end{tabular}

In terms of efficiency shown in Figure 15, both components achieved 99.30\% and 99.63\% for headrace canal and penstock respectively. Both of the civil components achieved an improvement of $0.23 \%$ for headrace canal and $5.54 \%$ for penstock as compared to the control design.

Value of Overall Micro-Hydro

\begin{tabular}{|l|r|r|r|}
\hline Civil Component & Efficiency & \multicolumn{1}{l|}{ lost } & \multicolumn{1}{l|}{ Value } \\
\hline Orifice / Side Intake & 100 & 5814.6664 & 1.719789118 \\
\hline Headrace Canal & 99.3025507 & 6588.435064 & 1.507225157 \\
\hline Settling Basin & 100 & 3955.976891 & 2.527820631 \\
\hline Penstock & 100 & 3171.415746 & 3.153165905 \\
\hline Forebay Tank & 99.62839067 & 11825.80947 & 0.842465718 \\
\hline & & Total Value & 9.750466528 \\
\cline { 3 - 5 } & & Average Value & 1.950093306 \\
\cline { 3 - 5 } & &
\end{tabular}

Figure 15: Overall value for micro-hydro.

As stated in Figure 16 , the average value achieved is 1.95 which sees an improvement from 1.906 of the control design. It is a major value improvement of value where the difference is 0.044 .

According to the evaluation of proposed idea 3 , it is rated at 5 as there is a very high potential for further development. It is as such because there is a huge leap of value increment as compared to the control design. In addition to that, efficiency, maintainability, constructability, environmental impact, overall construction cost and operational cost are all accounted for where it scored better than the control design. Hence, idea 3 is taken and being considered into further development stage. 


\begin{tabular}{|c|c|c|c|c|c|}
\hline No. & Description / Ideas & \multicolumn{2}{|l|}{ Advantages } & \multicolumn{2}{|l|}{ Disadvantages } \\
\hline 3 & $\begin{array}{l}\text { Evaluate the micro-hydro civil } \\
\text { components as a whole where } \\
\text { adjustments made to modify overall } \\
\text { output }\end{array}$ & $\begin{array}{l}\text { - Overall micro } \\
\text { structures are d } \\
\text { output perforn } \\
\text { each other is co } \\
\text { - Only critical se } \\
\text { be adjusted }\end{array}$ & $\begin{array}{l}\text { power plant for civil } \\
\text { ned as a whole structure and } \\
\text { that are inter-related with } \\
\text { ed } \\
\text { parameters are required to }\end{array}$ & $\begin{array}{l}\text { - Changes / adjust } \\
\text { structures are not }\end{array}$ & $\begin{array}{l}\text { ent made to the civil } \\
\text { efinite and not specific }\end{array}$ \\
\hline Efficiency & Maintainability & Constructability & Environmental Impact & $\begin{array}{l}\text { Overall } \\
\text { Construction Cost }\end{array}$ & Operational Cost \\
\hline$\checkmark$ & $\sqrt{ }$ & $\sqrt{ }$ & $\sqrt{ }$ & $\checkmark$ & $\checkmark$ \\
\hline$\underline{\text { Rating }}$ & $\begin{array}{l}\text { Comments / Justifications } \\
\text { The idea is preceded as it has }\end{array}$ & high potential. & & & \\
\hline
\end{tabular}

Figure 16: Evaluation of proposed idea no. 3.

\section{Conclusion}

\section{CONCLUSION}

Hydropower project offers great opportunities for sustainable energy development for rural areas. Micro-hydro power plants are deemed the cheapest, domestic and renewable resource energy (Maximilien, 2013). Hence, strategies in rural Sarawak development in terms of electrical supply need to include micro-hydropower system as it is one of the more reliable sources of renewable energy generation. In this study, focus is placed on developing a micro-hydro project in Kampung Assum though VE procedures and methodologies.

In pre-workshop studies, preliminary data and feasibility study data are obtain from Kampung Assum adjacent river, Sungai Sebarong. According to the preliminary data obtained, the gross head, measured flow, least flow and water level is suitable for small power generation system. Further analysis of the data shows that micro-hydro power plant is the suitable choice for the proposed site. From the preliminary report data, it is also noted that 100 households will be utilizing the power generating system where initial assumption of one household electrical usage is about 150 Watts. In addition to that, feasibility studies are conducted to ensure that constructing a micro-hydro power plant at Kampung Assum is reasonable. The results from the feasibility studies further prove that micro-hydro construction at Kampung Assum is feasible and the location is in very favorable conditions.

During workshop study, there were several different phases conducted for VE evaluation process. The process included information phase, function analysis stage, creative phase, development and evaluation phase and presentation phase. During information phase, the functions of civil components of micro-hydro power plant were determined and eventually the basic layouts of micro hydro were drafted out.

For creative phase, ideas to improve the value of micro-hydro power plant were being generated. There are two main criteria in determining and evaluating the value of micro-hydro power plant. Firstly, the quality aspect of the micro-hydro power plant for civil structures. Quality of the micro-hydro power plant are determined and evaluated in such a way that it is not over-designed or under-design. Performance, reliability and durability of the micro-hydro plant falls in the determination of quality aspect. In addition to that, material selection also plays a crucial role in determining the quality component of the micro-hydro power plant. Other criteria to consider when evaluating and determining the value of micro-hydro power plant is the costing factor of the plant. 
Costing of micro-hydro power plants is very important as there are budgets involved. Basically, it acts as a determining factor on whether micro-hydro power plant is able to have more financial feasibility as compared to other energy supply alternatives.

A control baseline design was produced so that comparison can be made with design that has done VE studies and applications. The baseline cost for constructing micro hydro power plant is RM $31,171.76$. Besides that, the efficiency rating for headrace canal is $99.07 \%$ and penstock efficiency rating at $94.09 \%$. Overall average value of the control design is rated at 1.906 . This output result is based on the conventional practice when designing a micro hydro power plant (Upadhayay, 2009).

This study shows that evaluation of the micro-hydro civil components as a whole where adjustments made to modify overall output is the most prominent idea. Hence, from the tabulated findings, it was determined the most significant idea that could greatly affect the overall micro-hydro value where the idea helped in improving the efficiency and reduced the cost required to construct the power plant. This study demonstrates that VE studies can be conducted on micro-hydro power plant construction projects. From this study, it is found out that there is an improvement of value up to 17\% from the original design. There are significant improvement of the efficiency of headrace canal and penstock where overall cost was reduced through VE practices.

\section{Acknowledgements}

The authors would like to acknowledge the funding provided for this project. The project is carried out under the Universiti Malaysia Sarawak SGS grant no: 02(S137)/1112/2014(02)

\section{References}

[1] Ando, R. (2005). Evaluation for Improvement Plan of Highways by Applying Value Engineering, Eastern Asia Society for Transportation Studies. Vol. 6, 1021-1035

[2] Dell'Isola, A. (1988). Value Engineering in the Construction Industry, $3^{\text {rd }}$ Edition. Washington: Smith, Hinchman \& Grylls, 65-66.

[3] Jaapar, A. Maznan, N.A., and Nawawi, M. (2012). Implementation of Value Management in Public Projects, Proceedings of the ASIA Pacific International Conference on Environmental-Behavior Studies, Giza, Egypt, $2^{\text {nd }}$ November, 78-79.

[4] Locke, M.B. (2001). Recent Developments in Value Management, Proceedings of the paper presented at the International Construction Conference 2003, Kuala Lumpur Malaysia, $5^{\text {th }}$ June.

[5] Maximilien, N. (2013). Design, Costing and Feasibility of Bukaba Micro Hydro Power Plant: A Rwanda Rural Electrification Case Study, Department of Energy Technology, KTH School of Industrail Engineering and Management, Stockholm, 11-20.

[6] Ong, H.T. (2003). Quality and Value Management in Construction - Achieving Excellence through ValueManaged Quality System (VMQS), Proceedings of the $6^{\text {th }}$ Hong Kong Institute of Value Management (HKIVM) International Conference, Hong Kong, $26^{\text {th }}$ November, 2-3

[7] Sadawi, U.E. (2008). A Value Engineering Methodology for Low Income Housing Projects in Gaza Strip, Science in Construction Management, 1: 8-9.

[8] Steven, H. (2003). Comparisons Between and Combinations of Different Approaches to Accelerate Engineering Projects, Department of Engineering and Technology Management, University of Pretoria, South Africa.

[9] The Malaysian Reserve. (2014) Tapping on Malaysia's Hydro Potential. Available from: <http://themalaysianreserve.com/main/sectorial/green-growth/5907-tapping-on-malaysias-hydro-potential>. Accessed on $22^{\text {nd }}$ December 2014. 
[10] Upadhayay, S. (2009). Evaluating the Effectiveness of Micro Hydropower Projects in Nepal, Faculty of the Department of Environment Studies, San Jose State University, 33-38. 